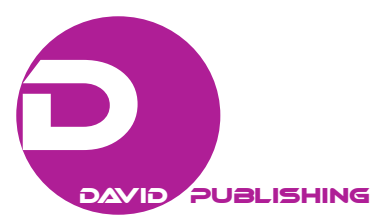

\title{
Innovations in the Financial World-Conceptual Issues of Digital Currency Development
}

\author{
Lali Chagelishvili-Agladze, Koba Chagelishvili \\ Tbilisi Teaching University, Tbilisi, Georgia
}

\begin{abstract}
In the article, we will discuss the crypto currencies, the basis of which is the growing demand for the future. The purpose of the work is to demonstrate the digital currency correlation with economic factors, such as the level of liquidity, the level of globalization and the quality of international relations, the needs of customers, and the requirements for the monetary system. As a result of the analysis of money evolution, the article provides a chart of money evolution. At the end of the thesis, there is a matrix of money, based on the basis of the use of digital currents and the possibility of using crypto currencies in real economy.
\end{abstract}

Keywords: evolution of money, cryptocurrency, money matrix

\section{Modern Monetary System}

From the very beginning of humanity, the need for a product is to produce products or services to be transferred to other products or services needed for it. In response to this need, the first manifestation of economic relations at the level of human development was the Barter Economy. There were also appropriate forms. The first economic relations were fulfilled through this system. However, the growth of the society has led to increased demand, which in turn demanded changes in the system of barter.

In response to new needs, new forms of settlement emerged in economic relations and started to use the basic values in transactions. The basic values were those things that everyone needed and they were easy to change at any time (Mongols-tea cones, the Madura Islands-salt pieces, etc.). Liquidity of key values was much higher than those used in barter relationships, as demand for them was high. This was the result of their success.

In the seventh century, the first metal coin was cut in Lydia. Since gold was rich in gold, the first coins were gold.

After the creation of metal coins, the key moment in the history of money was about the beginning of 10 century, creating the first paper money in China. This was the first type of paper money. This paper money was backed up by other precious metals (like gold and metal standard) and the state was its warrant. Its holder could at any time be able to change its so-called "hard" currency. This money kept all the properties of metal coins,

Lali Chagelishvili-Agladze, Doctor of Economic sciences, professor of Guram Tavartkiladze, Tbilisi Teaching University, Tbilisi, Georgia.

Koba Chagelishvili, Academic Doctor of Economics, professor of Guram Tavartkiladze, Tbilisi Teaching University, Tbilisi, Georgia.

Correspondence concerning this article should be addressed to Lali Chagelishvili-Agladze, 5 Samghereti street, 0101 Tbilisi, Georgia. 
but their use was more convenient in terms of extensive geography. After China's experience, paper money has spread widely across the globe.

The modern monetary system has been established in the previous century. During the Great Depression, federal reserves could not provide increased demands that led to massive bankruptcy of banks, and despite attempts by President Nixon in 1971 to introduce new standard, sailing courses, the end of the gold standard, and the euro of commodity money. This phenomenon was followed by a chain reaction around the world. Unlike trademarks, maternity money, which is used today, is more flexible, because its emission may be in demand and its control and stabilization is monetary policy.

In addition, the spread of the Internet made it possible to use electronic money in the world. Today, every bank has Internet banking services from which it is possible to transfer money from one point to another, in the shortest possible time and at a reasonable price. Many types of cards (debit, credit, etc.) are also used for settlement. This means that all the means are flexible today's money systems and more or less respond to new challenges that emerged in the post-industrial economy. Based on the above, it is clear that the system of monetary system changes the new demands of the evolution and economy of society.

In the 21 st century, the electronic business, or even the classic business forms of electronic business, have played a big role in the world economy. There are many companies that carry out their activities in the Internet space, and therefore sells goods (or services) in the same space, which generates demand, compensation in electronic form, in the same space. The development of similar businesses leads to transactions, transfers of the transactions on a daily basis. This tendency leads to more demand for more flexible and cheap means of electronic payment system.

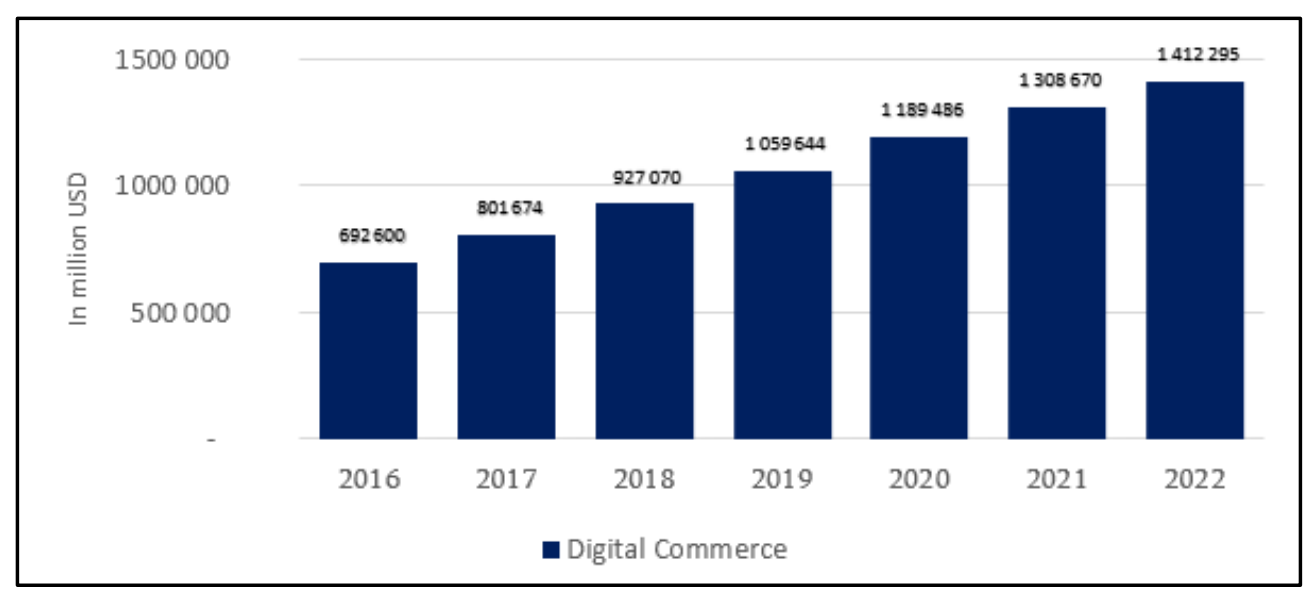

Figure 1. Growth trend of digital commerce volume

(Source: https://www.statista.com/outlook/296/109/digital-payments/united-states\#market-revenue).

One of the most important features of modern monetary systems is the need for a third trustworthy party that creates grave problems and makes transactions ineffective.

Modern money systems also have a risk of fraud (or so-called, double-spending) risk. This is a significant risk, which increases the efficiency of modern systems.

At the same time, in the beginning of the 21 century, there is a system of electronic payment system based on blocking technologies. By means of which two interested parties can make a settlement without third-party intervention. This mechanism will protect sellers and buyers, they will not need to collect/request extra 
information and on the other hand - quote. A similar system also significantly reduces transaction price and time. The system's protection ensures that honest rings in this chain will always exceed any unscrupulous group that ensures system security and sustainability.

\section{Cryptocurrency and Money Matrix}

Development of monetary systems is closely linked to the development of economy. If we develop this development history for a long period of time, it can easily be used for a number of periods: barter age, age of metal coins, timing of money, and the present maternal money. If we consider each of these periods in relation to the economic situation of the world, we can easily see the closer correlation with economic factors, such as the level of liquidity, the level of globalization and the quality of international relations, the needs of consumers, and the demands of the monetary system. In addition to the qualitative changes of these factors, the monetary system is changing in response; this evolutionary process can be seen as follows:

Table 1

Evolution of Money Characteristics

\begin{tabular}{|c|c|c|c|}
\hline & Liquidity & Globalization & Demands \\
\hline Barter period & Low liquidity & $\begin{array}{l}\text { Globalization is at the first level, } \\
\text { at the level of communities and } \\
\text { tribes. Geographical units are very } \\
\text { local and small. }\end{array}$ & $\begin{array}{l}\text { Only satisfy the fundamental } \\
\text { needs. }\end{array}$ \\
\hline Metal coins period & $\begin{array}{l}\text { A relatively high level of liquidity. } \\
\text { It is necessary to have a smaller } \\
\text { threshold of value, and the } \\
\text { diversity of goods increases }\end{array}$ & $\begin{array}{l}\text { The process of globalization is at } \\
\text { the initial stage. There are already } \\
\text { countries and they have economic } \\
\text { relations with each other. }\end{array}$ & $\begin{array}{l}\text { Money acquires state identity. The } \\
\text { storage feature is added to the } \\
\text { money. Countries need monopoly } \\
\text { on its emissions and produce } \\
\text { certain economic policies and } \\
\text { international trade. }\end{array}$ \\
\hline $\begin{array}{l}\text { Commodity money } \\
\text { period }\end{array}$ & $\begin{array}{l}\text { Growing economy needs high } \\
\text { liquidity on products. Diversity of } \\
\text { products is quite rising. }\end{array}$ & $\begin{array}{l}\text { Globalization level is high and } \\
\text { growing. International trade is } \\
\text { simplified. International } \\
\text { companies and central or private } \\
\text { banks appear. }\end{array}$ & $\begin{array}{l}\text { The money is required for the } \\
\text { transport simplicity and high } \\
\text { security. Big transactions are } \\
\text { performed. Countries are making } \\
\text { monetary policies. Increasing } \\
\text { demand for banking services and } \\
\text { international monetary } \\
\text { relationships. }\end{array}$ \\
\hline Maternal money & $\begin{array}{l}\text { The diversification of assets is } \\
\text { very high, the economy needs high } \\
\text { liquidity and flexibility of the } \\
\text { monetary system. }\end{array}$ & $\begin{array}{l}\text { Globalization level is high. The } \\
\text { role of international companies in } \\
\text { the world economy is great, the } \\
\text { money system will be required to } \\
\text { make a great speed and the ability } \\
\text { to perform remote operations. }\end{array}$ & $\begin{array}{l}\text { Monetary policy takes a major } \\
\text { role in the economies of the } \\
\text { countries, becoming one of the } \\
\text { main economic instruments. } \\
\text { Intensity and volume of } \\
\text { international trade is very high and } \\
\text { is characterized by a growing } \\
\text { tendency. Electronic economy } \\
\text { develops and occupies an } \\
\text { important part in the world } \\
\text { economy-electronic payments } \\
\text { and high mobility. }\end{array}$ \\
\hline
\end{tabular}

As the scheme outlines, the demands of the modern information century, where there is a high level of innovation and innovative technologies, certain factors have been added. Liquidity can be said that the assets have been added to digital assets, the rise of digital commerce, in the whole of the economy, the frequency and growing tendency when the whole economic cycle of the product does not go beyond the economic 
space-goods or services are manufactured and sold for this space and the pay is made in the same sphere. This requires an appropriate remuneration system for which electronic money is used. In addition, the globalization level has been significantly increased and growing around the globe over time, geographical factors in economic relations creates a lesser obstacle - all this requires the monetary system to keep these changes. The rise of globalization and digital technologies in daily life has brought new challenges for monetary systems, such as high level of anonymity, appropriate speed for Internet space, high reliability, and avoiding third-party interference in economic relations. The contemporary monetary system in this context suggests that this system needs change and development to address these new challenges. Therefore, it may be assumed that economic instruments based on the newly created blocking technology, including cryptographic currency, can be considered as a new stage of historical evolution of monetary systems.

However, before the crypton currency appeared, there is still a face of electronic money that we meet and use everyday. These are bank accounts, deposits, etc. This electronic part of the money is part of the usual cash system. Payment and Market Infrastructure-a glossary of terms used in payments and settlement systems-defines money as follows: Money denominated in modern currency (in traditional sense) includes physical forms (checks and banknotes) of money And other electronic expressions of money as central bank (deposits in the central bank as possible Used for payments) or cash for commercial banks. Electronic money (E-money) is separated by the same organization, defines the following: a unit stored on a device such as a chip or a hard disk on a computer.

The above electronic money is denominated, as well as standard money, central or commercial banks and can be easily replaced and withdrawn. The above electronic form of money can be considered as an intermediate link in the development process that gives maternity money to maximize flexibility and liquidity in order to respond to modern challenges. The electronic form of money allows to make electronic trading, although it is accompanied by all the discomfort or challenge that the physical forms of money, since it is only electronic manifestation of this system and does not have any independent features.

In order to get a crypton currency from the place of modern money, it must satisfy three classical functions of money. But it is different from other known money systems, so it is necessary to take into account the possibilities in this regard.

George Selgin (2013) used his "Synthetic Comodity Money", a monetary matrix that allows different and other monetary standards to be distinguished. Through the same matrix, we think that it is possible to show a more cryptic currency in the money system.

Based on the analysis of the monetary standard, it may be possible to determine its place in matrix. In the matrix, since the goods have internal value and can be used not with the monetary function, it will be placed in the left column, and since it is deficient, we can attribute the category of deficit and will be placed in the corresponding box.

The maternity standard has two characteristics, it has no internal value and therefore its non-monetary use is impossible and it has no absolute limit of supply, but its delivery is conditional, so in the matrix of the money, it will occupy the lower right tray.

From this, it is clear that if the supply limit is absolutely absolutely dependent on natural resources, and if conditional, it depends on the monetary policy and laws of the state that can not guarantee the guaranteed outcome. To satisfy the matrix, it is necessary to define a monetary standard when it has some non-monetary 
use, but supply deficit is conditional. Case Durable Standard (Coase, 1972) may be a product of which there is a monopoly, but its the supply volume does not depend on natural resources. This is possible if the monopolist has exclusive technology for its production or others. In this case, it determines the volume of its supply. In such a case, these commodities will require firmness and longevity.

Monopolist can increase its supply to achieve short-term goals, but if the supply is not stabilized at the level when the value of the goods is equal to the marginal value of the economy, the rational customer will no longer buy it. According to the statement, if a monopolist offers to buy back the product at a lower price, it indicates that it is going to maintain the supply deficit. The second method is that the monopolist will prove to the public that it is not going to exaggerate the delivery of the so-called public destruction. In this case, the monopolist periodically destroys existing products to show that they want to maintain the price at marginal cost levels (Bulow, 1982).

Therefore, we can fill the third drawer in the matrix of the seal, because we have a fixed standard with a certain internal value and not a monetary use, but its supply deficit is conditional, so it will occupy the bottom left corner.

\section{Synthetic Trading Standard}

To fill the fourth field of matrix, SEALI offers a system that it calls synthetic goods. At first glance, this standard is very similar to maternity money. The main resemblance is that in this case the money does not have any inward value. The main difference is how it is controlled and managed. In the case of maternity leave, it is controlled by regulations set by certain bureaucrats, but in the case of the regulator and regulatory subject is the same, the control mechanism in some cases generates deficiencies and violations. As regards the synthetic product standards, regulations are built into the system and the emission process is absolutely predetermined and limited-this method eliminates the problems that the state may have to carry out the wrong monetary policies and supply. This means that there is no need for any centralized system that monitors money management, but it is self-controlled. The synthetic standard can be perceived as a compromise option. Money management does not happen from central systems, and at the same time, it does not depend on natural resources. The agreement is required before the system runs, and the terms of the agreed agreement no longer change. Based on all of the above, we can fill the four trays of matrix.

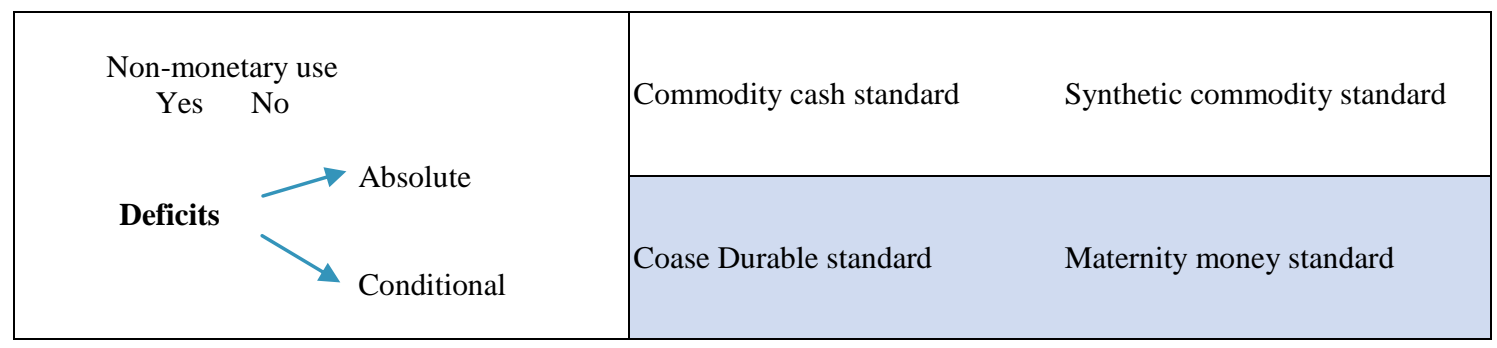

Figure 2. Money matrix.

For the justification of the above, we can recall the history of the Iraqi Swedish Dinar, when the US-imposed restrictions in the 1990 ended the distribution of the Iraqi dinar in Iraq with the Swiss technology in Iraq. Saddam Hussein released a new currency-Saddam Dinar. He destroyed old money printing technology and the old dinar was declared legitimate, which resulted in almost all of Iraq being abused. In the north of Iraq, people refused to use the new currency and continued to use the old dinar. 
The new monetary system was created with a fixed amount of money and no monetary institution was ruled by it, there was no authority to be able to carry out the monetary policy and interfere with the whole customer. This money did not have any inward value or any goods backed up. His emission was impossible, because there was no printing technology, on the contrary, the banknotes passed and over time. The value of this monetary unit was created only by the public agreement; it was used as a remedy.

If we exclude the characteristics of "Swiss Dinar", we will see its similarity with synthetic commodity and cryptic currencies. Their emission is absolutely limitless, they do not have an internal value and their management is not centralized. The "Swiss Dinar" course was stabilized in 1998 and maintained stability until 2003, when America did not invade Iraq and the entire country in the same currency, the monetary policy did not begin (Остальский, 2010).

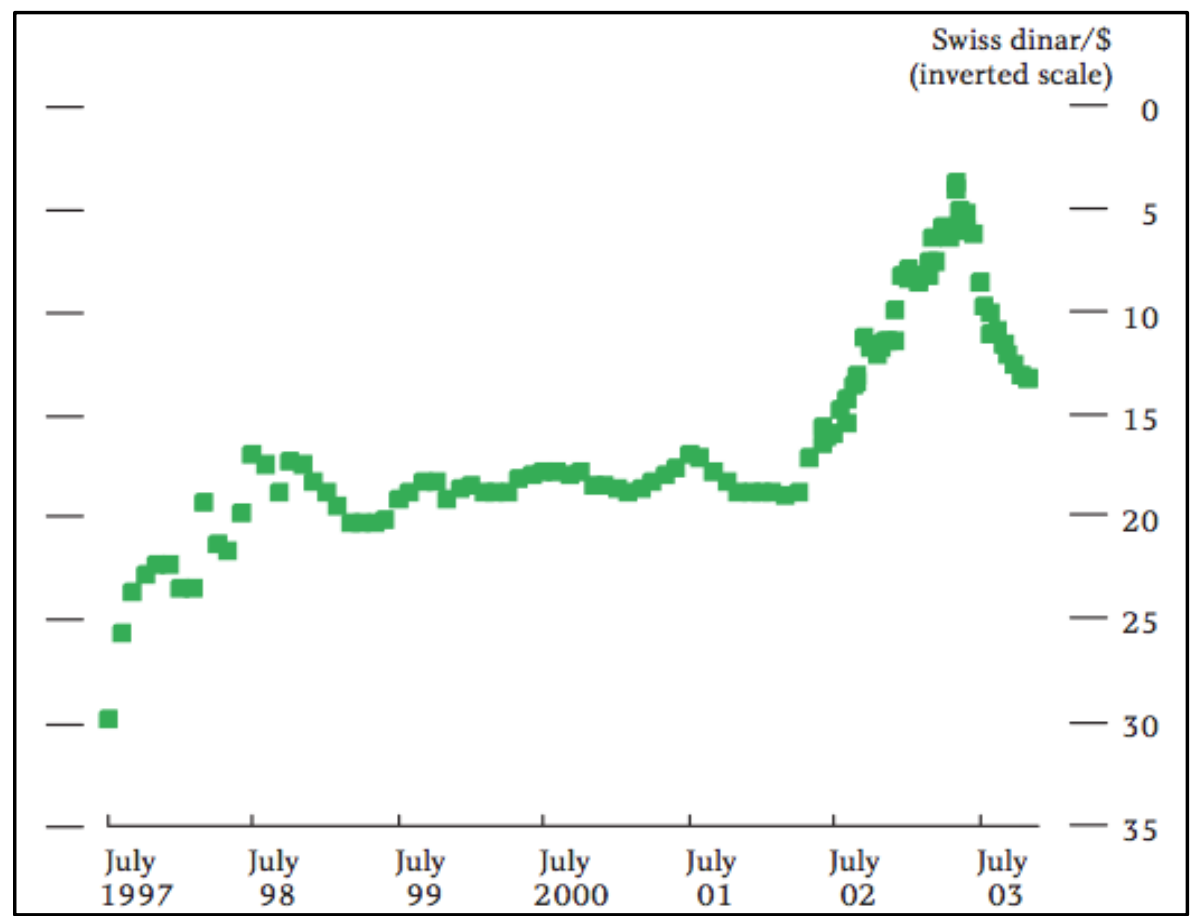

Figure 3. Swiss Dinar/Dollar exchange rate (Source: King, 2004).

\section{Conclusion}

Depending on the above, we can say that the use of this standard is possible in real economy and can be justified, because in our example, this standard ensured the stability of money. Crypto currency offers a new money system that will have the opportunity to deal with those challenges. No systems are able to answer. Consequently, we may note that crypto currency has the potential to be a future settlement system that will respond to all the demands of modern economic processes and to be used in the real economy as a major and subsidized currency.

\section{References}

Aeon. (2012). Blockchain technology will revolutionize far more than money: It will change your life. Here's how it actualiy works. Retrieved from https://aeon.co/essays/how-blockchain-will-revolutionise-far-more-than-money

Brito, J. (2012). Grinberg Reuben on the legality of bitcoin. Retrieved from https://techliberation.com/2012/01/31/reuben-grinberg/ 
Bulow, J. (1982). Durable-goods monopolists. Journal of Political Economy, 90(2), 314-332.

Coase, R. H. (1972). Durability and monopoly. Journal of Law and Economics, 15(1), 143-149.

Committee on Payments and Market Infrastructures. (2015). Digital currencies. Retrieved from https://www.bis.org/cpmi/publ/d137.pdf

Dyhrberg, A. H. (2016). Bitcoin, gold and the dollar-A garch volatility analisis. Finance Research Letters, 16, 85-92.

King, M. (2004). The institution of monetary policy. American Eagle Review, 92(2).

Nakamoto, S. (2009). A peer-to-peer electronic cash system. Retrieved from https://bitcoin.org/bitcoin.pdf

National Taxpayers Union Foundation. (1999). Interview with milton friedman. Retrieved from https://www.youtube.com/watch?v=mlwxdylnmxm\&feature=youtu.be

Reuben, G. (2011). Bitcoin: An innovative alternative digital currency. Hastings Science \& Technology Law Journal, 4, 160

Rodrigue, J. P. (2013). The geography of transport systems (3rd ed.). New York: Routledge.

Rosenfeld. M. (2011). Comment on if bitcoins catch on, will people get used to having so few? Retrieved from http://bitcointalk.org/index.php?topic=4234.msg6149\#msg61491 (suggesting using mBTC, uBTC and nBTC for small amounts of bitcoins

Selgin, G. (2013). Synthetic comodity money. Journal of Financial Stability, 17, 92-99.

The European Central Bank (ESB). (2012). Virtual Currency Schemes. Retrieved from https://www.ecb.europa.eu/pub/pdf/other/virtualcurrencyschemes201210en.pdf

Whelan, K. (2013). How is bitcoin different from the dollar? Retrieved from http:/www.forbes.com/sites.karlwhelan/2013/11/19/how-is-bitcoin-different-from-the-dollar

Ostalcki A. (2010). Small history of many. Sun-Peterburg, Amfora, 105-112. 